\title{
Description of the immatures of Linepithema humile Mayr (Hymenoptera: Formicidae)
}

\author{
DANIEL R. SOLIS ${ }^{1}$, EDUARDO G. P. FOX ${ }^{1}$, MÔNICA L. ROSSI ${ }^{2}$ \\ and ODAIR C. BUENO ${ }^{1}$
}

${ }^{1}$ Centro de Estudos de Insetos Sociais, Instituto de Biociências, São Paulo State University (UNESP), Rio
Claro, SP, Brazil.
${ }^{2}$ Laboratório de Histopatologia e Biologia Estrutural de Plantas, Centro de Energia Nuclear na Agricultura,
University of São Paulo (USP), Piracicaba, SP, Brazil.

\section{ABSTRACT}

Linepithema humile Mayr is an ant species originally native to South America that has been spread accidently throughout the globe through international trade. It is a serious urban and crop pest. Despite its economic importance, little is known about the larvae of this species apart from a brief description based on a few specimens. The present investigation is aimed at describing every immature stage of L. humile. Three larval instars were determined through the frequency distribution of the maximum width of head capsules from a sample of 525 larvae. The morphological descriptions were based on 150 eggs, 70 larvae, and 90 pupae examined by light and scanning electron microscopy. Some morphological characteristics reported to be typical of Linepithema Mayr larvae were confirmed - dolichoderoid body shape, presence of dorsal protuberance, sparse simple body hairs, presence of nine pairs of spiracles and dolichoderoid mandibles. We concluded that an earlier published description was based on queen larvae, and that the protuberance is only present in worker larvae. The information provided in this study may aid ant systematics and phylogenetics, as well provide a better understanding of the biology of this species.

Key terms: Argentine ant, Dolichoderinae, Dolichoderini, Iridomyrmex humilis, Larval instars, Tramp species.

\section{INTRODUCTION}

The genus Linepithema Mayr includes 35 described species and subspecies native to the Neotropical Region (Bolton et al., 2006). The most important species is Linepithema humile Mayr, which is originally native to the Paraná River drainage basin of Argentina, Brazil, Paraguay, and Uruguay (Wild, 2007). This species has been inadvertently introduced through international trade to many other countries and regions with Mediterranean climates, such as South Africa, Australia, the USA, Europe and New Zealand (Passera, 1994; Giraud et al., 2002; RouraPascual et al., 2004). It is both an urban and rural pest, with negative effects on native ant species and general flora (Shattuck, 1992; Vega and Rust, 2001). Linepithema humile is considered a tramp species, i.e. it presents poorly structured nests that can easily be moved, unicolonial populations, marked aggressiveness towards other ant species, polygyny, lack of mating flights, and small monomorphic workers (Passera, 1994).

Despite the great economic importance of the species, the larvae of L. humile are only superficially known from some biological notes and morphological measurements made by Newell and Barber (1913), and from a rather incomplete morphological description in Wheeler and Wheeler (1990). Both works were based on a few specimens, and without knowledge of

Correspondence to: Daniel Russ Solis, Centro de Estudos de Insetos Sociais, Instituto de Biociências, Universidade Estadual Paulista "Julio de Mesquista Filho" (UNESP), Av. 24-A, 1515, CEP 13506-900, Rio Claro, SP, Brazil, E-mail: entomo75@yahoo.com, Telephone: 55+19+35264160. 
the number of larval instars. Larval descriptions are paramount for ant systematics, and some characters can be applied to genus-level identification of specimens (Wheeler and Wheeler, 1976; Schultz and Meier, 1995). Moreover, larvae represent the basis of ant social organization (Hölldobler and Wilson, 1990), thus deeper knowledge about larval morphology is bound to clarify general biological aspects of ants (Fox et al., 2007).

The present study was aimed at describing every immature stage of $L$. humile with the aid of light and scanning electron microscopy.

\section{METHODS}

\section{Obtaining samples}

Nests of L. humile were obtained in 2005 in the municipality of Limeira (22 $39^{\circ} 03.93$ ''S and $\left.47^{\circ} 21^{\prime} 07.58^{\prime} ' \mathrm{~W}\right)$, São Paulo, Brazil, and colonies were reared in the laboratory (temperature $23-27{ }^{\circ} \mathrm{C}$ and $50-70 \%$ relative humidity). Immature forms were obtained from four of these colonies to be used in our descriptions. Our colonies were producing males, thus our samples include male larvae. Colonies of this ant species are constantly producing males (Passera et al., 1988). No gynes were observed.

Voucher specimens of eggs, larvae, and pupae were deposited in the Adolph Hempel Entomological Collection of the Centro de Pesquisa e Desenvolvimento de Sanidade Vegetal of Instituto Biológico, São Paulo, Brazil.

\section{Determining the number of larval instars}

In order to sort larvae of different developmental stages for description, it was necessary to determine the number of larval instars of L. humile. We opted for the methods described in Parra and Haddad (1989) to determine the number of instars. The maximum head widths of the larvae were measured $(\mathrm{N}=525)$ and plotted in a frequency distribution graph, in which the distinct frequency peaks are considered to indicate different larval instars, and the obtained number of larval instars was tested against Dyar's Rrule (Parra and Haddad 1989). The first larval instar and the last larval instar can be explicitly identified and used as reference to bracket others. First instar larvae are equivalent to the mature embryo, which can be measured in the egg through the transparent chorion, and last instar larvae have the developing pupa showing from within (also termed 'prepupae').

\section{Description of the immature forms}

The morphological descriptions were based on a total of 40 larvae with dorsal protuberance and 30 larvae without dorsal protuberance (belonging to all instars). These larvae were sampled from the most frequent peaks to ensure they belonged to the assigned instar. The larvae were analyzed under light microscope (Zeiss MC80 DX, with maximum magnification of 1000X) and a scanning electron microscope (LEO $435 \mathrm{VP}$, at $20.0 \mathrm{kV}$ ). With a stereomicroscope (Zeiss Stemi SV11, with maximum magnification of $66 \mathrm{X}$ ) equipped with a micrometric eyepiece, we could rapidly measure length and width of eggs $(\mathrm{N}=150)$ and larvae $(\mathrm{N}=209)$, head width and body length of pupae $(\mathrm{N}=90)$. Also, body length through spiracles - a mode of measuring larvae devised by Wheeler and Wheeler (1976) that accounts for body curvature - was determined for all described larvae based on spiracles. Terminology used in our larval descriptions was based on Wheeler and Wheeler (1976). Measurements, where applicable, are given as mean $\pm \mathrm{SD}$, followed by the range given in parentheses and the number $(\mathrm{N})$ of individuals analyzed.

All collected samples were fixed in Dietrich's solution $(900 \mathrm{ml}$ distilled water, $450 \mathrm{ml} 95 \%$ ethanol, $150 \mathrm{ml} 40 \%$ formaldehyde, $30 \mathrm{ml}$ acetic acid) for $24 \mathrm{~h}$ and then transferred and conserved in $80 \%$ alcohol. For scanning electron microscopy analysis, the samples were dehydrated in an acetone graded series (70-100\%; specimens being dipped for $5 \mathrm{~min}$ in each concentration), and critical-point dried 

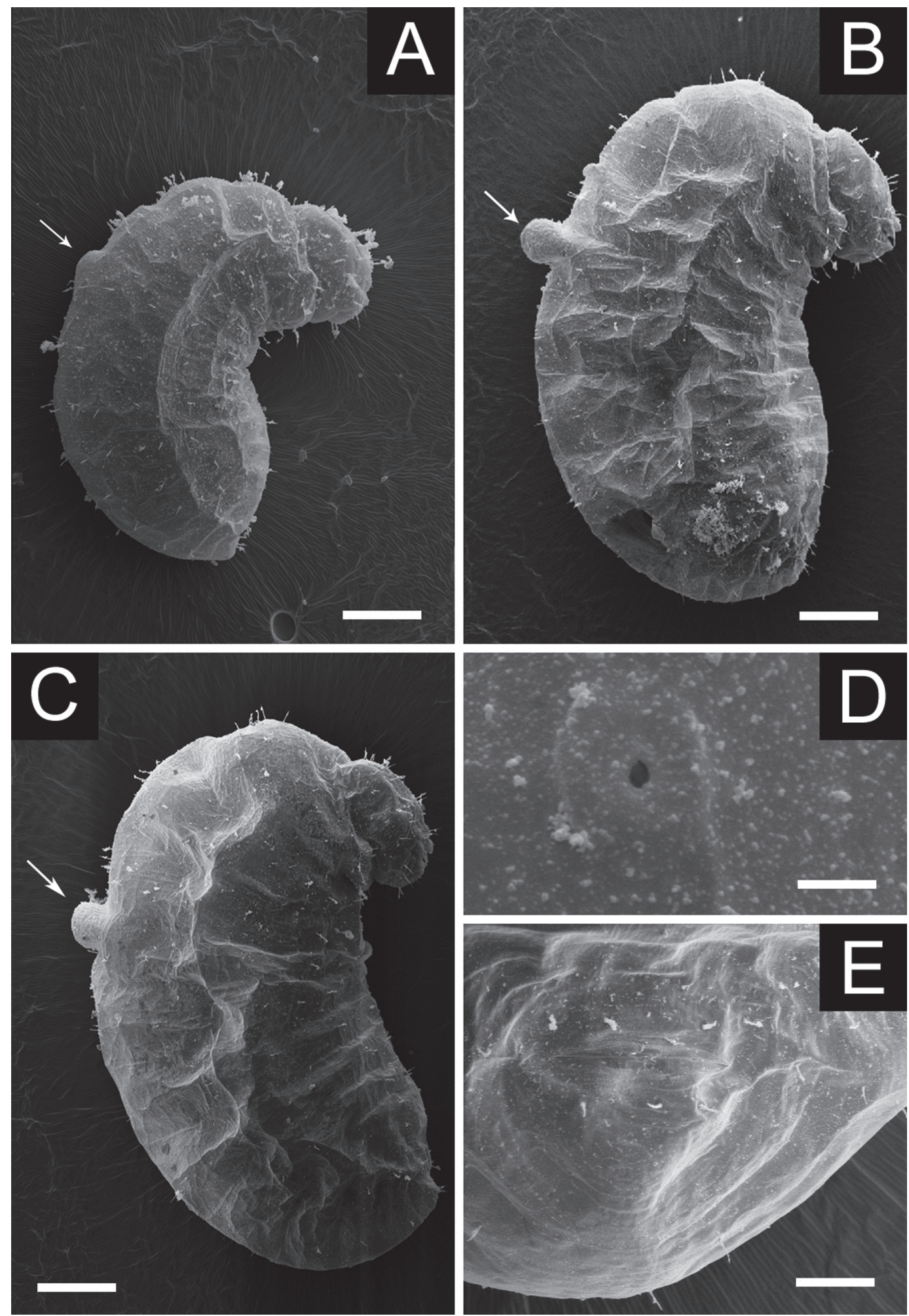

Figure 1: Linepithema humile larvae on side view: (A) First instar larva, (B) Third instar larva, (C) Pre-pupa with meconium (black arrow). White arrows indicate the dorsal protuberance; (D) Spiracle of a first instar larva; (E) Anus and surrounding region of a third instar larva. Scale bars: (A) $0.100 \mathrm{~mm}$; (B) $0.150 \mathrm{~mm}$; (C) $0.225 \mathrm{~mm}$; (D) $0.002 \mathrm{~mm}$; (E) $0.054 \mathrm{~mm}$. 
(Balzers CPD/030). Dried specimens were then attached to aluminum stubs with a double-faced conductive adhesive tape and were gold-sputtered with a Balzers SCD/ 050 sputterer. Observations and images were obtained as soon as possible from sample preparation. Prior to analysis under the light microscope, the larvae were warmed for $10 \mathrm{~min}$ in $\mathrm{KOH} 10 \%$ and placed in a small drop of glycerin on a microscope slide.

\section{RESULTS}

\section{Determining the number of larval instars}

The larvae could be sorted into two distinct morphological groups: those presenting a dorsal protuberance on the first abdominal segment (Fig. 1) and those lacking it (Fig. 7A). Larvae with the protuberance were more frequent $(83.8 \%$ of our sample of $\mathrm{N}=$ $525)$. These two types of larvae were separately plotted and described.

The resulting frequency distribution of larval head widths of both types of larvae yielded three distinct peaks (suggesting the existence of three instars), the first being the first instar larvae and the last formed by prepupae. The obtained number of instars yielded a good fit with Dyar's rule (Larvae with protuberance: $\mathrm{R}^{2}=0.85$; Larvae without protuberance: $\left.\mathrm{R}^{2}=0.85\right)$.

The resulting growth rate among the different instars for larvae with dorsal protuberance was 1.23 , where the firstsecond instar growth rate was 1.28 and the second-third instar growth rate was 1.17. The growth rate among the different instars of larvae without a dorsal protuberance was 1.29, where the first-second instar growth rate was 1.35 and the second-third instar growth rate was 1.22. Each immature stage is fully described as follows.

Egg

Ovoid, with delicate translucent chorion markedly separated from embryo. Mean egg length was $0.30 \pm 0.03 \mathrm{~mm}(0.26-0.34 \mathrm{~mm} ; \mathrm{N}$ $=150)$ and width $0.23 \pm 0.01 \mathrm{~mm}(0.21-0.26$ $\mathrm{mm} ; \mathrm{N}=150)$. Length: width ratio 1.30 .

\section{Larvae}

As the three different larval instars shared many characteristics, a general description (valid to larvae with and without dorsal protuberance) will be given first, followed by descriptions of the characteristics unique to each instar.
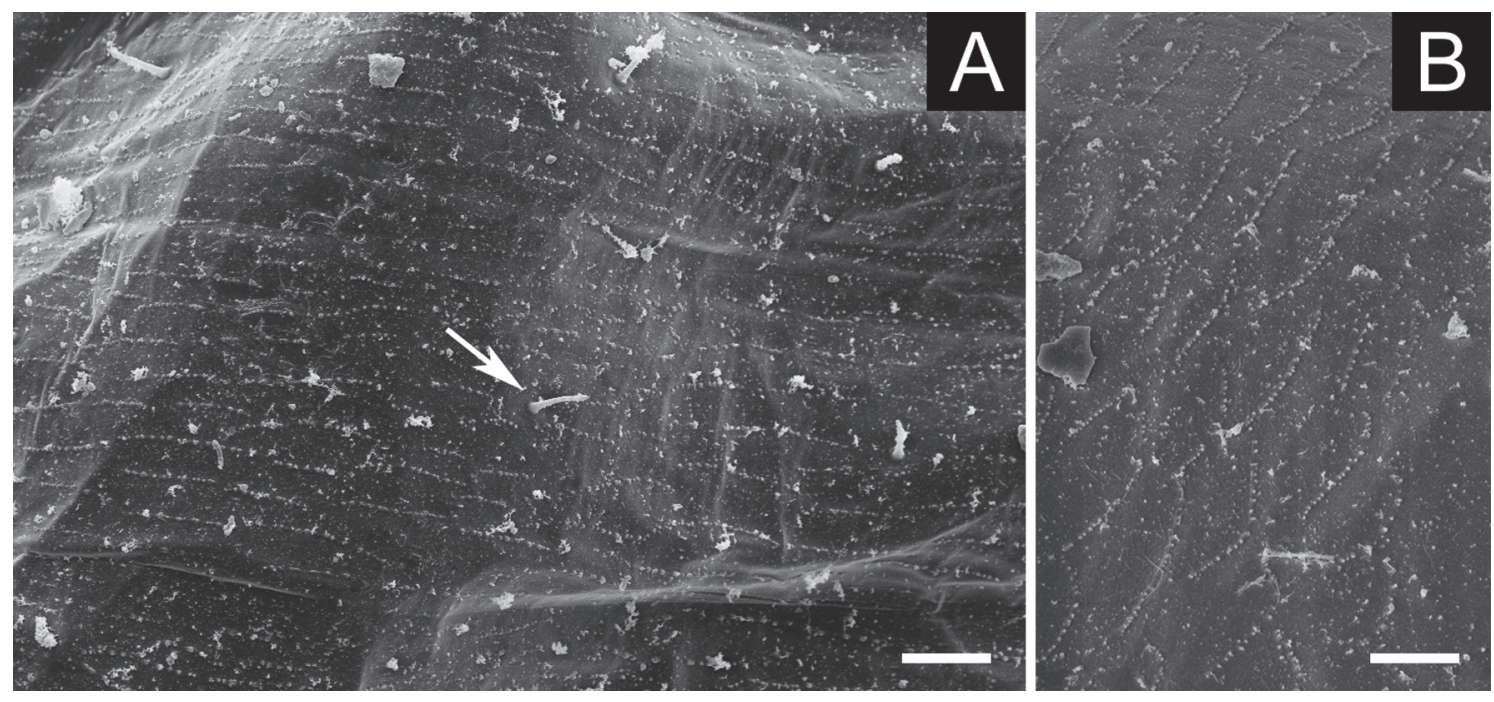

Figure 2: Tegument surface of Linepithema humile larvae, showing transverse rows of spinules: (A) Ventral region of third instar larva - arrow: simple hair; (B) Side view of second instar larva. Scale bars: (A) $0.020 \mathrm{~mm}$; (B) $0.010 \mathrm{~mm}$. 
BODY: Whitish and with anus markedly subterminal in position (Figs. 1E, 7B). Body shape dolichoderoid (Figs. 1A, 1B, 1C, 7A), i.e. "short, stout, plump, straight or slightly curved, with both ends broadly rounded; anterior end formed by enlarged dorsum of prothorax; head ventral, near anterior end; no neck; somites indistinct" (Wheeler and Wheeler, 1976). Body covered with simple hairs and spinules arranged in transversal rows (Fig. 2). Hairs of the thoracic region, especially those of a row on the ventral side of the prothorax (see Figs. 3B, 7D) longer than those of the abdomen. Nine pairs of unornamented spiracles, two thoracic and seven abdominal (Fig. 1D). HEAD CAPSULE: Subhexagonal in shape (Fig. 3A). Antennae were slight elliptical
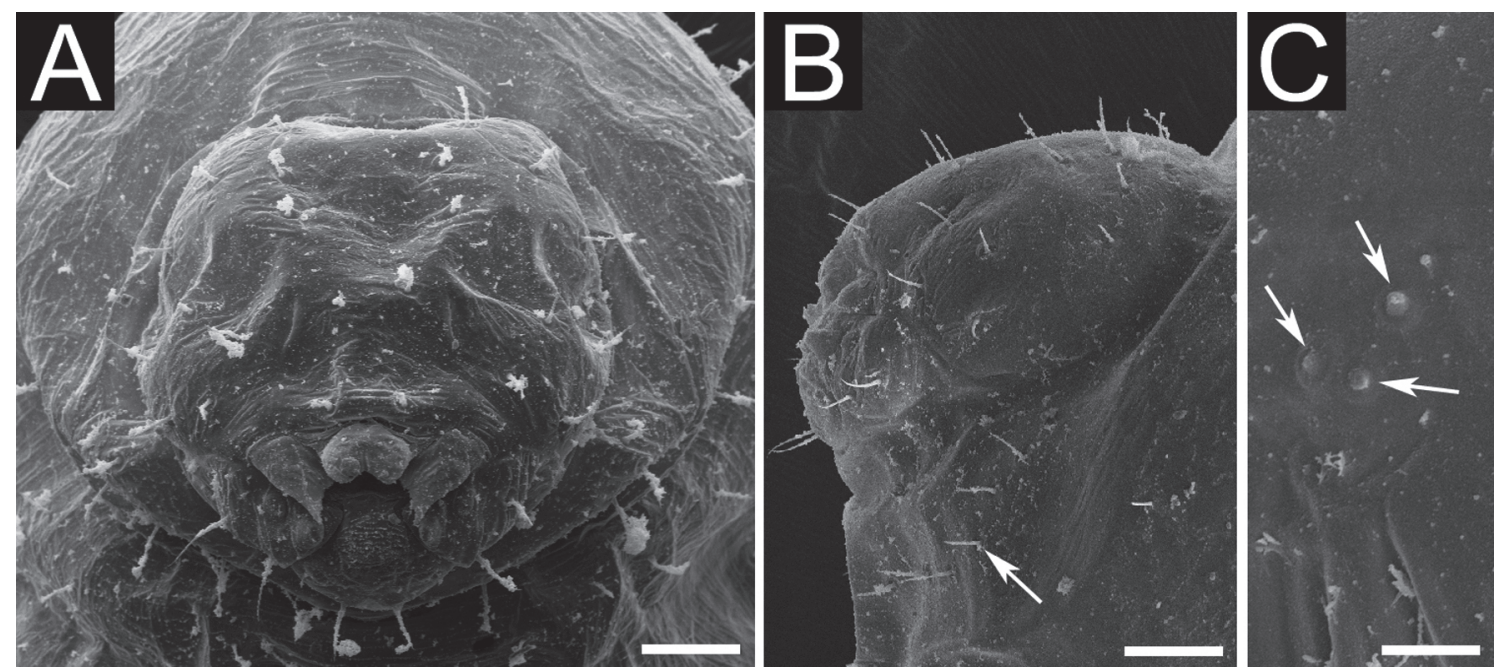

Figure 3: Head capsule of Linepithema humile larvae: (A) Frontal view of a third instar larva; (B) Side view of a third instar larva - arrow: row of simple hairs on the ventral region of prothorax; (C) Antenna of a first instar larva - arrows: basiconic sensilla. Scale bars: (A) $0.049 \mathrm{~mm}$; (B) 0.068 $\mathrm{mm}$; (C) $0.005 \mathrm{~mm}$.
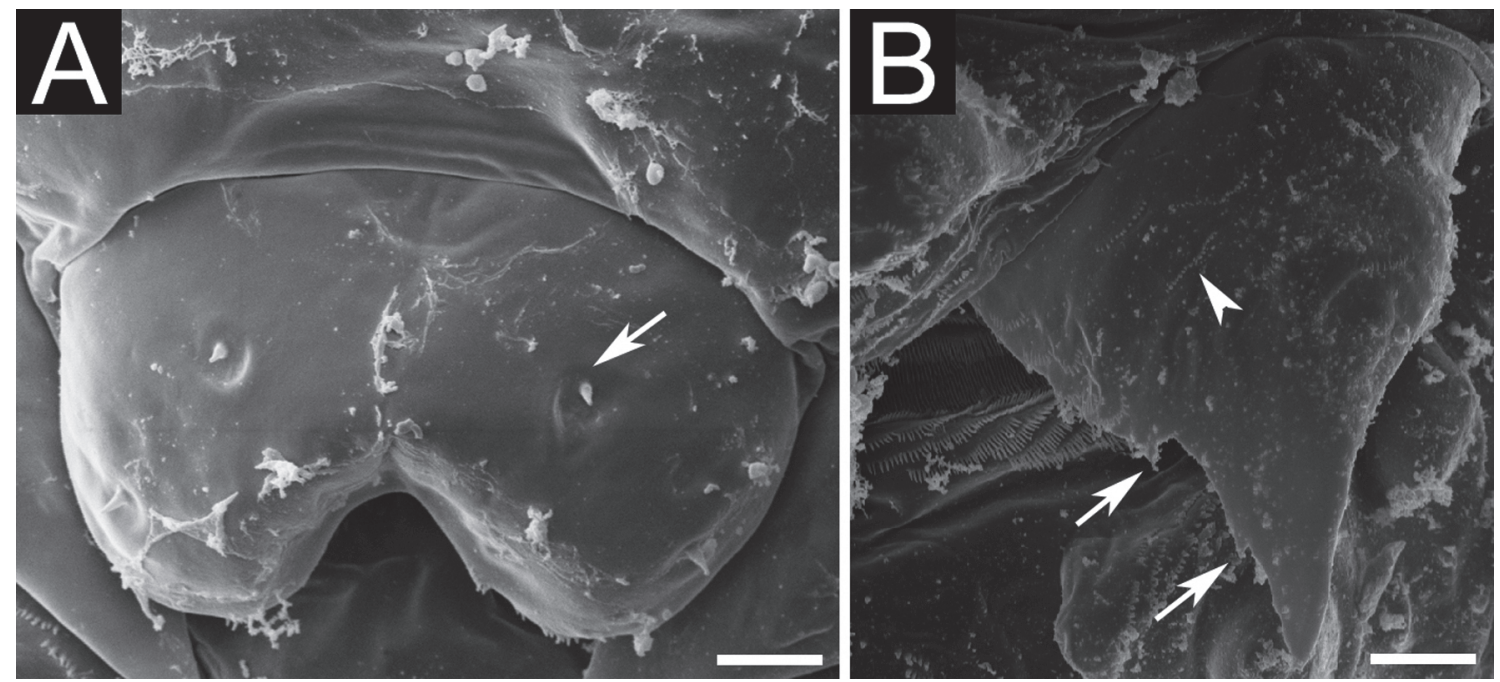

Figure 4: Mouthparts of Linepithema humile larvae: (A) Labrum of second instar larva - arrow: setaceous sensillum; (B) Mandible of third instar larva, showing denticles on blade (arrows) and rows of spinules (arrowhead). Scale bars: (A) $0.012 \mathrm{~mm}$; (B) $0.007 \mathrm{~mm}$. 
elevations bearing three basiconic sensilla (Figs. 3C, 7C). Head hairs all simple and longer than body hairs, except in first instar larvae without dorsal protuberance. Head hairs distributed as follows (Figs. 3A, 3B): nine to ten over each gena, four on clypeus, and none on frons, vertex or occipital border. Clypeus clearly delimited. MOUTHPARTS: Labrum bilobed with four setaceous sensilla (0.002 mm long; $\mathrm{N}=6)$ on the anterior surface (Figs. 4A, 7E) and two basiconic sensilla on the ventral surface; posterior surface with transversely-arranged rows of spinules and some isolated spinules Mandibles roughly dolichoderoid in shape, defined by Wheeler and Wheeler (1976) as: "basal part inflated and narrowed more or less abruptly to the distal part, which is slender and sharp-pointed; no medial teeth or blade", and sclerotized, but presenting two small teeth on the blade (Figs. 4B, 7E); two enclosed sensilla on base of mandibles. Maxilla conoidal in shape (Fig. 5A) with spinules arranged in transversal rows on apex, two simple hairs on ventral surface and two or three setaceous sensilla $(0.002 \mathrm{~mm}$ long; $\mathrm{N}=3$ ); maxillary palpus a cluster of five sensilla, one setaceous, two basiconic and two encapsulated (Fig. 5B); galea a skewed peg with two basiconic sensilla (Fig. 5A). Labium elliptical and presenting (Fig. 6A) a group of spinules arranged in transversal rows on the region behind the slit-like sericteries, two major and four minor simple hairs, and one basiconic sensillum by each extremity of the sericteries. Labial palpus a cluster of five sensilla (Fig. 6B), one setaceous, two enclosed and two basiconic. Mouth entrance displaying hypopharynx covered with elongate spinules arranged in dense transverse rows (Fig. 6C).

\section{Larvae with dorsal protuberance (workers)}

First larval instar. BODY: Larvae $0.57 \pm$ $0.09 \mathrm{~mm}$ long $(0.40-0.81 \mathrm{~mm} ; \mathrm{N}=42)$ and $0.29 \pm 0.05 \mathrm{~mm}$ wide $(0.18-0.40 \mathrm{~mm} ; \mathrm{N}=$ 42). Total number of hairs between 200-300, $0.021 \pm 0.005 \mathrm{~mm}$ long $(0.015-0.033 \mathrm{~mm} ; \mathrm{N}$ $=50)$. Spiracle diameter $0.003-0.008 \mathrm{~mm}(\mathrm{~N}$ $=90)$, the first abdominal pair being the largest $(0.005-0.008 \mathrm{~mm} ; \mathrm{N}=10)$ and the others of about the same size. Body length through spiracles $0.83 \pm 0.06 \mathrm{~mm}(0.72-0.94$ $\mathrm{mm} ; \mathrm{N}=10)$. Length of dorsal protuberance $0.071 \pm 0.009 \mathrm{~mm}(0.060-0.085 \mathrm{~mm} ; \mathrm{N}=$ 10). HEAD CAPSULE: Cranium $0.18 \mathrm{~mm}$
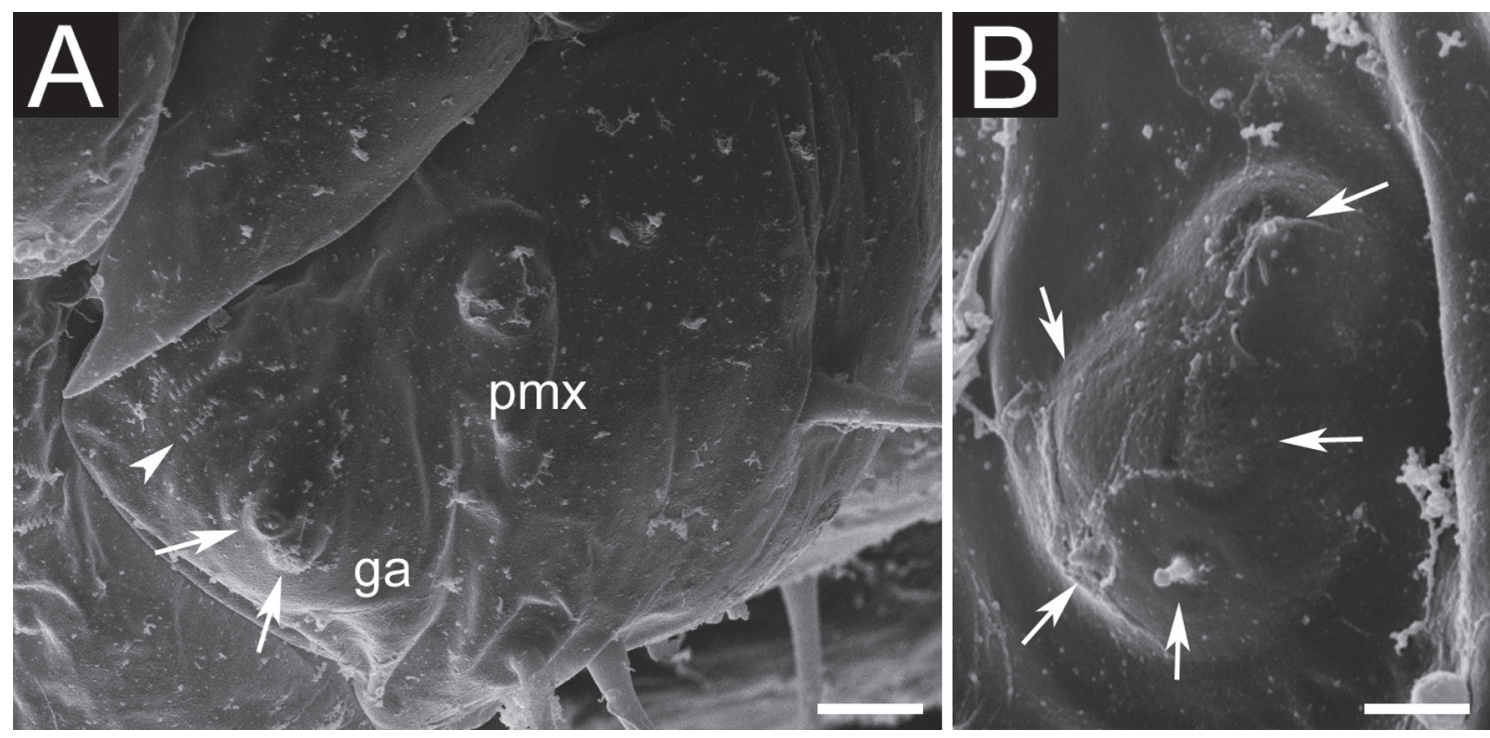

Figure 5: Mouthparts of Linepithema humile larvae. (A) Maxilla of first instar larva: galea (ga), maxillary palpus (pmx), transverse rows of spines (arrowhead) and apical sensilla (arrows); (B) Maxillary palpus of second instar larva - arrows: sensilla. Scale bars: (A) $0.008 \mathrm{~mm}$; (B) $0.002 \mathrm{~mm}$. 
wide $(\mathrm{N}=42)$. Head hairs $0.026 \pm 0.005 \mathrm{~mm}$ long (0.013-0.038 mm; $\mathrm{N}=50)$. MOUTHPARTS: Labrum $0.049 \mathrm{~mm}$ long and $0.021 \mathrm{~mm}$ wide. Mandibles $0.037 \pm$ $0.004 \mathrm{~mm}$ long $(0.028-0.040 \mathrm{~mm} ; \mathrm{N}=10)$. Maxillary hairs $0.034 \pm 0.004 \mathrm{~mm}$ long (0.030-0.043 mm; $\mathrm{N}=10$ ). Labium 0.081 $\mathrm{mm}$ long, with major hairs $0.034 \pm 0.003$ $\mathrm{mm}$ long (0.029-0.038 mm; $\mathrm{N}=10)$ and minor hairs 0.003-0.009 mm long $(\mathrm{N}=3)$.

Second larval instar. BODY: Larvae $0.78 \pm 0.14 \mathrm{~mm}$ long $(0.51-1.16 \mathrm{~mm} ; \mathrm{N}=$ $61)$ and $0.40 \pm 0.08 \mathrm{~mm}$ wide $(0.26-0.60$ $\mathrm{mm} ; \mathrm{N}=61)$. Total number of hairs between 200-400, $0.023 \pm 0.006 \mathrm{~mm}$ long (0.018-0.040 mm; $N=50)$. Spiracle diameter $0.003-0.010 \mathrm{~mm}(\mathrm{~N}=90)$, the first abdominal pair being the largest $(0.008$ $0.010 \mathrm{~mm} ; \mathrm{N}=10$ ) and the others of about the same size. Body length through spiracles $1.10 \pm 0.16 \mathrm{~mm}(0.84-1.37 \mathrm{~mm} ; \mathrm{N}$ $=10)$. Protuberance $0.102 \pm 0.015 \mathrm{~mm}$ long (0.075-0.128 mm; $\mathrm{N}=10)$. HEAD CAPSULE: Cranium $0.22 \mathrm{~mm}$ wide $(\mathrm{N}=$ $61)$. Head hairs $0.029 \pm 0.005 \mathrm{~mm}$ long (0.020-0.038 $\mathrm{mm} ; \mathrm{N}=50)$. MOUTHPARTS: Labrum $0.049 \mathrm{~mm}$ long and $0.023 \mathrm{~mm}$ wide. Mandibles $0.048 \pm$ $0.004 \mathrm{~mm}$ long (0.043- $0.053 \mathrm{~mm} ; \mathrm{N}=10)$.
Maxillary hairs $0.040 \pm 0.006 \mathrm{~mm}$ long (0.032-0.050 mm; $\mathrm{N}=10$ ). Labium 0.075 $\mathrm{mm}$ long, with major hairs $0.034 \pm 0.006$ $\mathrm{mm}$ long $(0.024-0.040 \mathrm{~mm} ; \mathrm{N}=10)$ and minor hairs $0.003 \mathrm{~mm}$ long $(\mathrm{N}=3)$.

Third larval instar. BODY: Larvae $1.23 \pm$ $0.29 \mathrm{~mm}$ long $(0.54-1.92 \mathrm{~mm} ; \mathrm{N}=73)$ and $0.59 \pm 0.12 \mathrm{~mm}$ wide $(0.31-0.83 \mathrm{~mm} ; \mathrm{N}=$ 73). Total number of hairs between 100-200, $0.024 \pm 0.005 \mathrm{~mm}$ long $(0.018-0.038 \mathrm{~mm} ; \mathrm{N}$ $=100)$. Spiracle diameter $0.005-0.013 \mathrm{~mm}(\mathrm{~N}$ $=180$ ), with first abdominal pair being the largest $(0.010-0.013 \mathrm{~mm} ; \mathrm{N}=20)$ and the seventh abdominal pair the smallest $(0.005-$ $0.008 \mathrm{~mm} ; \mathrm{N}=20$ ); others of about the same size. Body length through spiracles $1.91 \pm$ $0.18 \mathrm{~mm}$ (1.66-2.24 mm; $\mathrm{N}=20)$. Dorsal protuberance $0.127 \pm 0.013 \mathrm{~mm}(0.105-0.160$ $\mathrm{mm} ; \mathrm{N}=20)$. HEAD CAPSULE: Cranium $0.26 \mathrm{~mm}$ wide $(\mathrm{N}=73)$. Head hairs $0.030 \pm$ $0.005 \mathrm{~mm}$ long $(0.023-0.045 \mathrm{~mm} ; \mathrm{N}=100)$. MOUTHPARTS: Labrum $0.044 \mathrm{~mm}$ long and $0.025 \mathrm{~mm}$ wide. Mandibles $0.059 \pm 0.005$ $\mathrm{mm}$ long (0.053-0.073 $\mathrm{mm} ; \mathrm{N}=20)$ with some transversely arranged spines on anterior surface (Fig. 4B). Maxillary hairs $0.037 \pm$ $0.003 \mathrm{~mm}$ long $(0.030-0.040 \mathrm{~mm} ; \mathrm{N}=10)$. Labium $0.086 \mathrm{~mm}$ long, with major hairs $0.037 \pm 0.005 \mathrm{~mm}$ long $(0.027-0.043 \mathrm{~mm} ; \mathrm{N}$
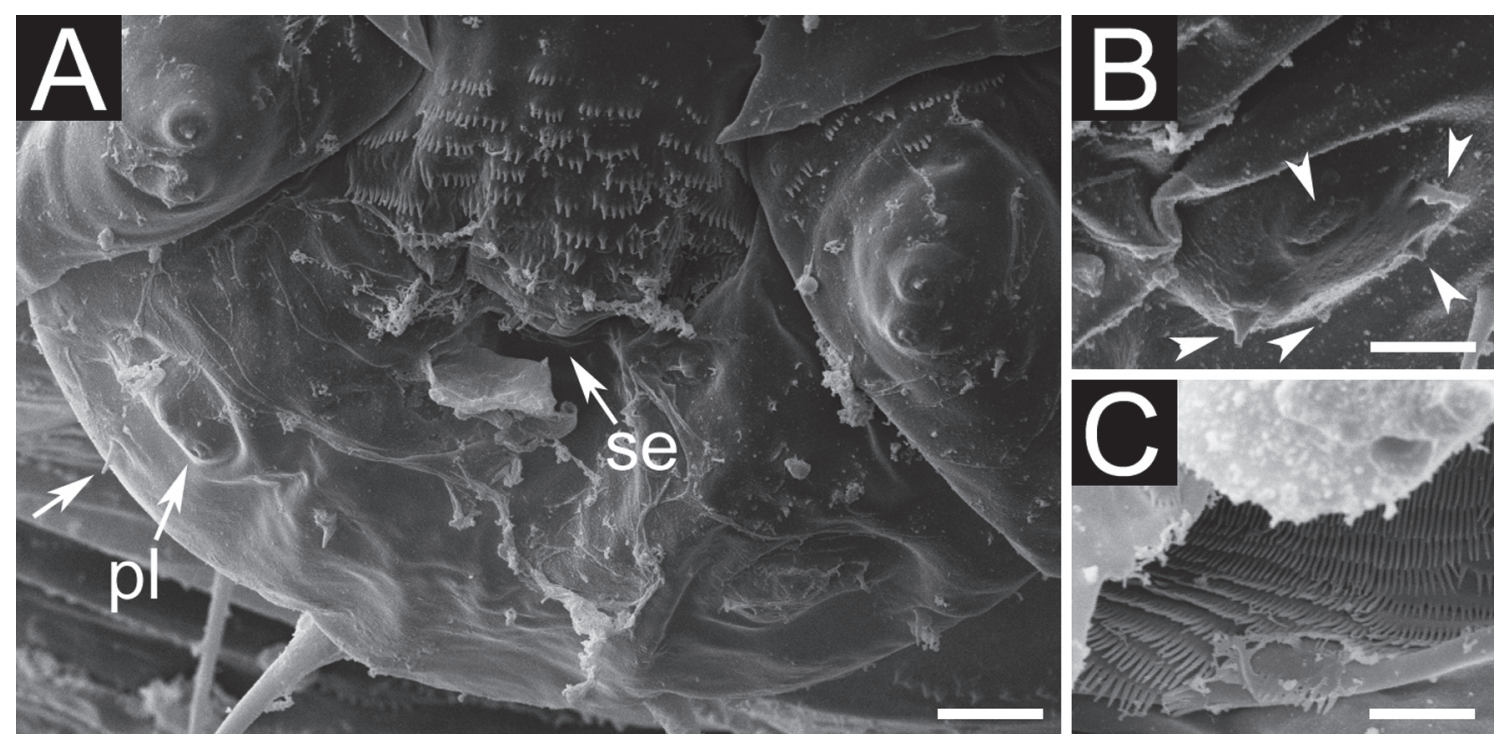

Figure 6: Mouthparts of Linepithema humile larvae. (A) Labium of second instar larva: labial palpus (pl), sericteries (se), minor hair (arrow); (B) Labial palpus of third instar larva with sensilla (arrowheads); (C) Mouth entrance of third instar larva, displaying hypopharynx covered with elongate spines. Scale bars: (A) $0.008 \mathrm{~mm}$; (B) $0.003 \mathrm{~mm}$; (C) $0.005 \mathrm{~mm}$. 
$=10)$ and minor hairs $0.003-0.005 \mathrm{~mm}$ long $(\mathrm{N}=3)$.

Larvae without dorsal protuberance (males)

First instar larvae. BODY: Larvae $0.62 \pm$ $0.08 \mathrm{~mm}$ long $(0.44-0.74 \mathrm{~mm} ; \mathrm{N}=11)$ and
$0.32 \pm 0.05 \mathrm{~mm}$ wide $(0.22-0.41 \mathrm{~mm} ; \mathrm{N}=$ 11). Total number of hairs 100-150, $0.019 \pm$ $0.005 \mathrm{~mm}$ long $(0.012-0.034 \mathrm{~mm} ; \mathrm{N}=50)$. Spiracle diameter 0.001-0.006 $\mathrm{mm}(\mathrm{N}=90)$, with first abdominal pair being the largest (0.005-0.006 mm; $\mathrm{N}=10)$ and the seventh abdominal pair the smallest (0.001-0.002 $\mathrm{mm} ; \mathrm{N}=10$ ); others may be or may not be
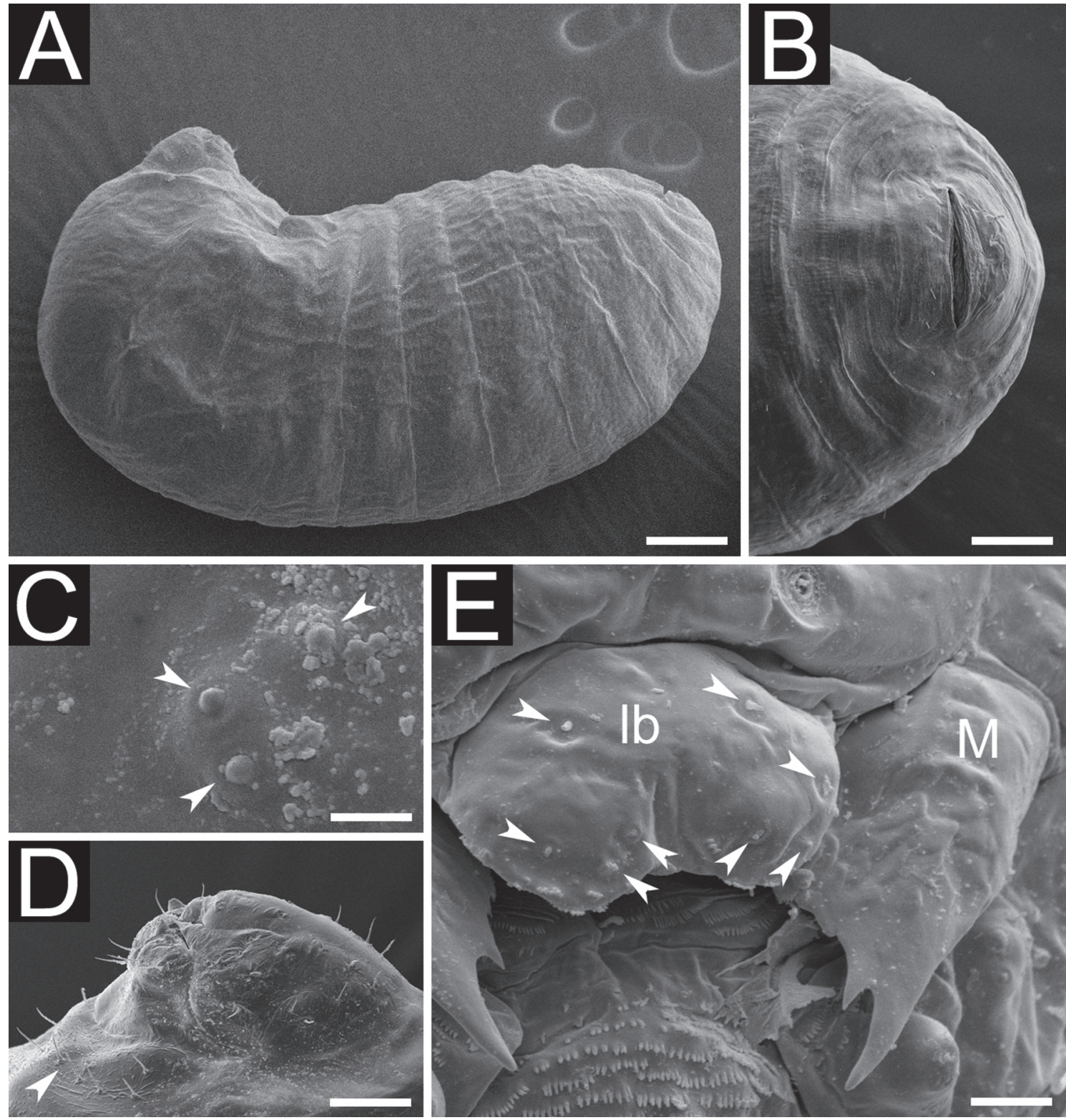

Figure 7: Third instar larva of Linepithema humile without dorsal protuberance (i.e. male larva): (A) side view; (B) terminal end and anus; (C) antenna (arrowheads indicate sensilla); (D) head on side view (arrowhead indicates row of hairs); (E) mouthparts ( $\mathrm{M}$ - mandibles, lb - labrum with sensilla indicated by arrowheads). Sizes of scale bars: (A) $0.247 \mathrm{~mm}$, (B) $0.145 \mathrm{~mm}$, (C) $0.003 \mathrm{~mm}$, (D) $0.085 \mathrm{~mm}$, (E) $0.010 \mathrm{~mm}$. 
of the same approximate size. Body length through spiracles $0.76-1.00 \mathrm{~mm}(\mathrm{~N}=8)$. HEAD CAPSULE: Cranium $0.18 \mathrm{~mm}$ wide $(\mathrm{N}=11)$. Head hairs $0.019 \pm 0.005 \mathrm{~mm}$ long (0.010-0.031 mm; $\mathrm{N}=50)$. MOUTHPARTS: Mandibles $0.041 \pm 0.002 \mathrm{~mm}$ long $(0.039$ $0.046 \mathrm{~mm} ; \mathrm{N}=10)$. Maxillary hairs $0.031 \pm$ $0.002 \mathrm{~mm}$ long $(0.026-0.034 \mathrm{~mm} ; \mathrm{N}=10)$. Major hairs over labium $0.028 \pm 0.003 \mathrm{~mm}$ long (0.023-0.031 mm; $\mathrm{N}=10)$.

Second instar larvae. BODY: Larvae $1.18 \pm 0.26 \mathrm{~mm}$ long $(0.62-1.50 \mathrm{~mm} ; \mathrm{N}=$ 12) and $0.62 \pm 0.12 \mathrm{~mm}$ wide $(0.43-0.77$ $\mathrm{mm} ; \mathrm{N}=12)$. Total number of hairs 100 $150,0.022 \pm 0.006 \mathrm{~mm}$ long (0.013-0.035 $\mathrm{mm} ; \mathrm{N}=50)$. Spiracle diameter 0.003 $0.009 \mathrm{~mm}(\mathrm{~N}=63)$, the first abdominal pair being the largest $(0.007-0.009 \mathrm{~mm} ; \mathrm{N}=7)$ and the others of about the same size. Body length through spiracles 1.00-1.69 $\mathrm{mm}(\mathrm{N}=$ 7). HEAD CAPSULE: Cranium $0.24 \mathrm{~mm}$ wide $(\mathrm{N}=12)$. Head hairs $0.030 \pm 0.005$ $\mathrm{mm}$ long (0.020-0.043 $\mathrm{mm} ; \mathrm{N}=50)$.
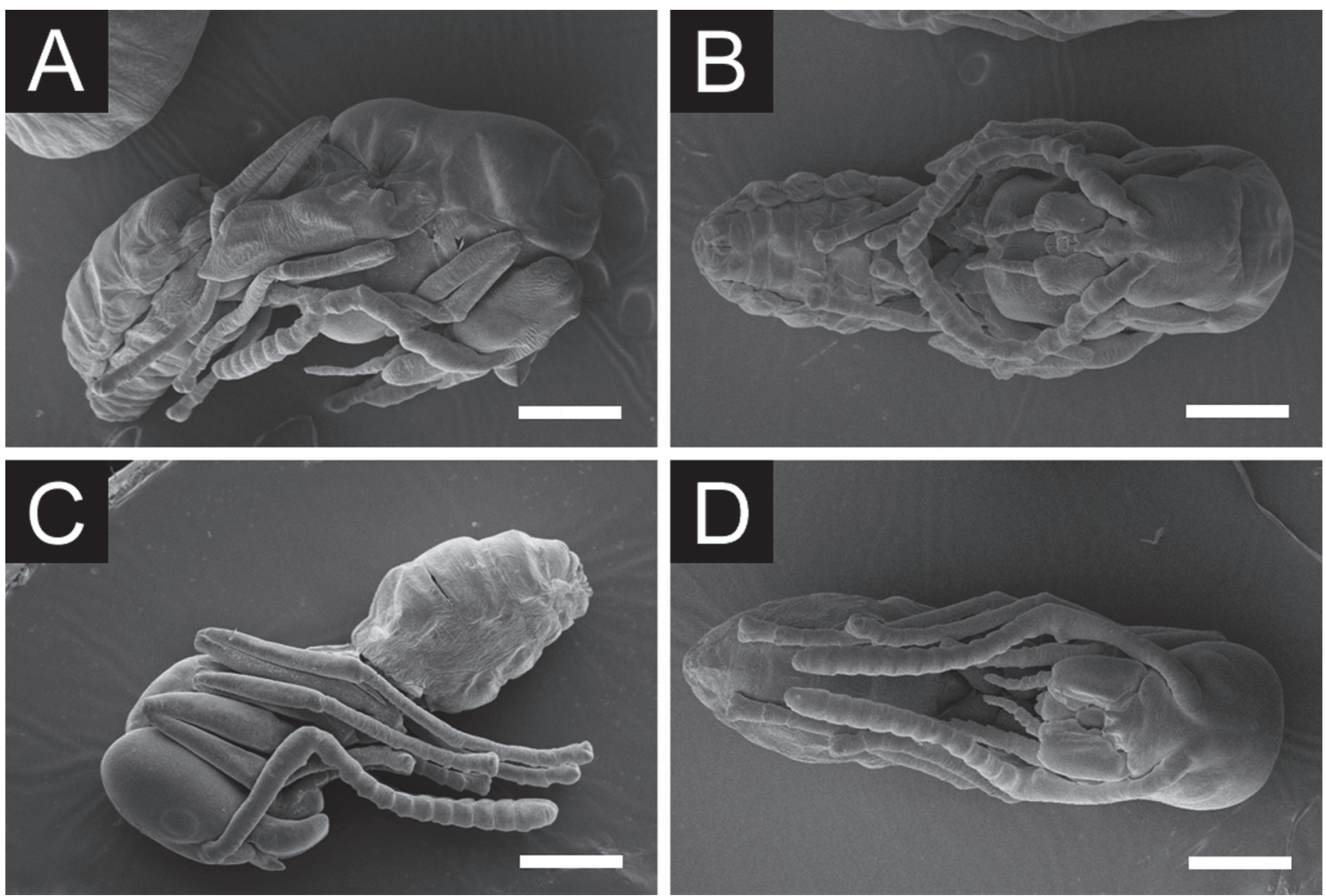

MOUTHPARTS: Mandibles 0.048-0.055 $\mathrm{mm}$ long $(\mathrm{N}=8)$. Maxillary hairs $0.038 \pm$ $0.005 \mathrm{~mm}$ long (0.030-0.045 mm; $\mathrm{N}=10)$. Major hairs over labium $0.038 \pm 0.004 \mathrm{~mm}$ long (0.030-0.043 mm; $\mathrm{N}=10)$.

Third instar larvae. BODY: Larvae 1.59 $\pm 0.41 \mathrm{~mm}$ long $(1.25-2.59 \mathrm{~mm} ; \mathrm{N}=10)$ and $0.77 \pm 0.13 \mathrm{~mm}$ wide $(0.62-1.03 \mathrm{~mm} ; \mathrm{N}$ $=10)$. Total number of hairs 100-150, 0.023 $\pm 0.008 \mathrm{~mm}$ long $(0.013-0.038 \mathrm{~mm} ; \mathrm{N}=$ $50)$. Spiracle diameter $0.005-0.013 \mathrm{~mm}(\mathrm{~N}$ $=90)$, with the first abdominal pair (0.010$0.013 \mathrm{~mm} ; \mathrm{N}=10$ ) being larger than the others, which may or may not be of the same approximate size. Body length through spiracles $2.13 \pm 0.47 \mathrm{~mm}$ (1.69$2.97 \mathrm{~mm} ; \mathrm{N}=10)$. HEAD CAPSULE: Cranium $0.26 \mathrm{~mm}$ wide $(\mathrm{N}=10)$. Head hairs $0.031 \pm 0.006 \mathrm{~mm}$ long $(0.018-0.045$ $\mathrm{mm} ; \mathrm{N}=50)$. MOUTHPARTS: Labrum $0.040 \mathrm{~mm}$ long and $0.015 \mathrm{~mm}$ wide. Mandibles $0.059 \pm 0.003 \mathrm{~mm}$ long $(0.055$ $0.063 \mathrm{~mm} ; \mathrm{N}=10$ ) with some transversely

Figure 8: Pupae of Linepithema humile: (A) male pupa on side view, (B) male pupa on ventral view, (C) worker pupa on side view, (D) worker pupa on ventral view. Sizes of scale bars: (A) $0.480 \mathrm{~mm}$, (B) $0.470 \mathrm{~mm}$, (C) $0.430 \mathrm{~mm}$, (D) $0.410 \mathrm{~mm}$. 
arranged spines on anterior surface. Maxillary hairs $0.044 \pm 0.005 \mathrm{~mm}$ long (0.038-0.050 mm; $\mathrm{N}=10)$. Labium 0.097 $\mathrm{mm}$ long; major hairs over labium $0.040 \pm$ $0.005 \mathrm{~mm}$ long $(0.035-0.050 \mathrm{~mm} ; \mathrm{N}=10)$.

\section{Pupae}

Upon early development, pupae are whitish, getting darker with time until imago stage, eyes darkening first. Always exarate with no cocoon (Fig. 8). Pupae of workers $2.41 \pm$ $0.09 \mathrm{~mm}$ long $(2.19-2.63 \mathrm{~mm} ; \mathrm{N}=60)$ and pupae males $3.18 \pm 0.12 \mathrm{~mm}$ long (2.96$3.47 \mathrm{~mm} ; \mathrm{N}=30$ ). Maximum head width of worker pupae $0.69 \pm 0.03 \mathrm{~mm}(0.59-0.76$ $\mathrm{mm} ; \mathrm{N}=60$ ) and maximum head width of male pupae $0.66 \pm 0.03 \mathrm{~mm}(0.58-0.69 \mathrm{~mm}$; $\mathrm{N}=30$ ). Only white pupae were measured, of which $23.2 \%(\mathrm{~N}=151)$ were males.

\section{DISCUSSION}

\section{Description of the immature forms}

\section{Egg and Pupa}

Newell and Barber (1913) mentioned the eggs of L. humile measured $0.30 \mathrm{~mm}$ long $(0.27$ $0.34 \mathrm{~mm}$ ) and $0.20 \mathrm{~mm}$ wide $(0.19-0.24 \mathrm{~mm})$, which generally agrees with our findings. The same authors stated that sorting the three types of pupae (worker, males and queens) was easy as they were always longer than the respective mature larvae - workers about 2 $\mathrm{mm}$, males $3.04 \mathrm{~mm}$ long $(2.78-3.23 \mathrm{~mm}$; $\mathrm{N}=$ $10)$, and queens were much bigger and also easily recognizable by their "prominent wing pads" (Newell and Barber, 1913). These measurements agree with our findings and confirm that our samples did not include juvenile queen forms.

\section{Larvae}

Wheeler and Wheeler (1990) based their description of larvae of L. humile on nine mature larvae that were considerably larger than ours (body length through spiracles 4.4 $\mathrm{mm}$ ), and, based on the following traits: "Gonopod vestiges on AVIII and AIX: leg and wing vestiges present" (Wheeler and
Wheeler, 1990). They suggested they were describing reproductive larvae. Moreover, the article of Newell and Barber (1913) presented data on male and worker larvae that agree with ours, and noted that queen pupae are considerably larger than others. Thus, it is clear to us that the sample described in Wheeler and Wheeler (1990) included only juvenile queens.

It should be noted that the specimens described by Wheeler and Wheeler (1990) completely lacked a dorsal protuberance. The dorsal protuberance on the first abdominal segment is typical of Linepithema larvae (Shattuck, 1992), and most larvae in our samples had it. Body protuberances were shown to distinguish between reproductive and worker larvae in other Dolichoderinae species: Froggattella kirbyi Lowne (Wheeler and Wheeler, 1966), in which reproductives had no dorsal protuberances, while workers did, and Tapinoma sessile Say (Wheeler and Wheeler, 1951), in which reproductive larvae had greatly reduced posterodorsal protuberances in comparison to worker larvae. As the only reproductives in our sampled colonies were males, we assume reproductive larvae found (i.e. the larvae without dorsal protuberance) were always males. These reproductive larvae without protuberance were considerably smaller than those of the Wheelers's description, thus we assume theirs were based on last instar larvae of queens, which tend to be larger than the others (O’Neal and Markin, 1975; Wheeler and Wheeler, 1976; Torregrossa et al., 1982). Interestingly, the larvae described by Wheeler and Wheeler (1990) had an additional pair of spiracles, totaling ten. Yet, head capsule width was not measured by Wheeler and Wheeler (1990), so the number of larval instars of queen larvae still awaits closer investigation. We have not been able to obtain queen-producing colonies to date.

Moreover Newell and Barber (1913) and Passera et al. (1988) stated that sorting mature male larvae and mature worker larvae was easy based on their bodily dimensions - male larvae being $2.5 \mathrm{~mm}$ long and worker larvae averaging $1.7 \mathrm{~mm}$ long. Reproductive larvae in our samples were also considerably larger than worker larvae. However, general size should be 
regarded with caution in comparing specimens from different colonies, as different conditions (e.g. diet) can alter size, sometimes generating smaller individuals (Fowler et al., 1991).

Wheeler and Wheeler (1960) built a genus-level taxonomical system based on ant larvae that chiefly considered three morphological traits: body shape in profile, mandible shape and types of hairs found. From these traits, Wheeler and Wheeler (1951) built a key to mature larvae of the Dolichoderinae.

The body profile of L. humile was always dolichoderoid, as was observed in those few larvae of the same species by Wheeler and Wheeler (1990) and to other Linepithema by Shattuck (1992).

The mandibles of L. humile were dolichoderoid, as also observed by Wheeler and Wheeler (1990). However, we further identified two small teeth over the blade (Fig. 4B). Thus, in studies with other Dolichoderinae species, the presence of teeth should be carefully verified in mandibles presenting similar shape. Moreover, the mandibles of larvae without dorsal protuberance differ from those of the larvae with a dorsal protuberance (i.e. worker larvae) in presenting more prominent teeth.

Wheeler and Wheeler (1990) stated that the bodies of larvae of $L$. humile were covered with a few simple hairs and transverse rows of spinules: this pattern was verified to hold in all larval instars. The presence of only simple hairs is not unique to Linepithema (Shattuck, 1992), but has also been observed in other Dolichoderinae (Wheeler and Wheeler, 1951). Regarding the spinules, Wheeler and Wheeler (1951) mentioned their abundance depends on the genus of the larvae being analyzed: sometimes they can be present in reduced numbers. The body of Linepithema larvae is completely covered with spinules, except for the head.

Ant larvae usually present ten pairs of spiracles, two thoracic and eight abdominal, with half of the known genera presenting uniform small spiracles (Wheeler and Wheeler, 1976). Linepithema humile presented nine pairs of spiracles, which seems to be typical of the genus (Shattuck,
1992), with the first abdominal pair being the largest, also observed by Wheeler and Wheeler (1990). Wheeler and Wheeler (1990) reported ten pairs of spiracles in $L$. humile larvae, but, as already mentioned, they were dealing with queen larvae.

As mentioned in Wheeler and Wheeler (1976), all ant larvae have sericteries, but not all species weave silky cocoons, as is the case of all Dolichoderinae including L. humile.

Finally, this study presented a detailed description of the immature L. humile. Some general characteristics of Linepithema larvae (Shattuck, 1992) were confirmed - dolichoderoid body profile, dorsal protuberance, few simple body hairs, nine pair of spiracles, and dolichoderoid mandibles - and the number of larval instars of this species was determined for the first time. We took the care to measure structures that were overlooked in the earlier description, reporting how the sizes of these larval structures vary among the different instars: mandible length, head widths, spiracle diameter, body dimensions and length through spiracles. Additionally, we verified that the lack of a dorsal protuberance is typical of reproductive larvae within this species. We hope the information given can be applied to ant systematics, phylogeny, and add to the body of knowledge on general ant biology.

\section{ACKNOWLEDGEMENTS}

We would like to thank CAPES Institution for the financial support provided, Elliot Watanabe Kitajima and Francisco André Ossamu Tanaka (NAP/MEPA ESALQUSP) for granting ample access to microscopy facilities, Jacques Hubert Charles Delabie (CEPLAC) for kindly identifying our specimens, and John $\mathrm{T}$. Longino for his constructive criticism on the earlier versions of the manuscript.

\section{REFERENCES}

BOLTON B, ALPERT G, WARD PS, NASKRECKI P (2006) Bolton catalogue of Ants of the World: 17582005. Cambridge: Harvard University Press. CD-ROM. 
FOX EGP, SOLIS DR, JESUS CM, BUENO OC, YABUKI AT, ROSSI ML (2007) On the immature stages of the crazy ant Paratrechina longicornis (Latreille 1802) (Hymenoptera: Formicidae). Zootaxa 1503: 1-11.

FOWLER HG, FORTI LC, BRANDÃO CRF, DELABIE JHC, VASCONCELOS HL (1991) Ecologia nutricional de formigas. In: PANIZZI AR, PARRA JRP (eds) Ecologia nutricional de insetos e suas implicações no manejo de pragas. São Paulo: Editora Manole. pp: 141233.

GIRAUD T, PEDERSEN JS, KELLER L (2002) Evolution of supercolonies: The argentine ants of southern Europe. Proc Natl Acad Sci USA 99: 6075-6079.

HOLLDOBLER B, WILSON EO (1990) The Ants. Cambridge: Harvard University Press. 732pp.

NEWELL W, BARBER TC (1913) The Argentine ant. Washington DC: US Dept of Agriculture - Bureau of Entomology. 98pp.

ONEAL J, MARKIN GP (1975) The larval instars of the imported fire ant, Solenopsis invicta Buren (Hymenoptera: Formicidae). J Kansas Entomol Soc 48: 141-151.

PARRA JRP, HADDAD ML (1989) Determinação do número de instares de insetos. Piracicaba: FEALQ. 49pp.

PASSERA L, KELLER L, SUZZONI JP (1988) Control of brood male production in the Argentine ant Iridomyrmex humilis (Mayr). Insect Soc 35: 19-33.

PASSERA L (1994) Characteristic of tramp species. In: WILLIAMS DF (ed) Exotic ants: Biology, impact and control of introduced species. San Francisco: Wetsview Press. pp: 23-43.

ROURA PASCUAL N, SUAREZ AV, GOMEZ C, PONS P, TOUYAMA Y, WILD AL, PETERSON AT (2004)
Geographical potential of argentine ants (Linepithema humile) in the face of global climate change. Proc $\mathrm{R}$ Soc London Ser B Biol Sci 271: 2527-2534.

SCHULTZ TR, MEIER R (1995) A phylogenetic analysis of the fungus-growing ants (Hymenoptera: Formicidae: Attini) based on morphological characters of the larvae. Syst Entomol 20: 337-370.

SHATTUCK SO (1992) Generic revision of the ant subfamily Dolichoderinae (Hymenoptera: Formicidae). Sociobiology 21: 1-181.

TORREGROSSA JP, FEBVAY G, KERMARREC A (1982) Larval instars of the worker caste in the attine ant, Acromyrmex octospinosus (Hymenoptera: Formicidae). Colemania 1: 141-147.

VEGA SJ, RUST MK (2001) The Argentine ant - a significant invasive species in agricultural, urban and natural environments. Sociobiology 37: 3-25.

WHEELER GC, WHEELER J (1951) The ant larvae of the subfamily Dolichoderinae. Proc Entomol Soc Washington 53: 169-210.

WHEELER GC, WHEELER J (1960) The ant larvae of the subfamily Myrmicinae. Ann Entomol Soc Am 53: 98110 .

WHEELER GC, WHEELER J (1966) The ant larvae of the subfamily Dolichoderinae: supplement. Ann Entomol Soc Am 59: 726-732.

WHEELER GC, WHEELER J (1976) Ant larvae: Review and synthesis. Mem Entomol Soc Washington 7: 1-108.

WHEELER GC, WHEELER J (1990) Notes on ant larvae. Trans Am Entomol Soc 115: 457-473.

WILD AL (2007) Taxonomic revision of the ant genus Linepithema (Hymenoptera: Formicidae). Univ Calif Publ Entomol 126: 1-159. 